\title{
A META-ANALYSIS ON THE EFFECT OF INQUIRY LEARNING MODEL ON STUDENTS' MATHEMATICAL PROBLEM-SOLVING SKILLS
}

\author{
Rizki Ramadhani ${ }^{*}$, Dadang Juandi ${ }^{2}$, Elah Nurlaelah ${ }^{3}$ \\ 1,2,3 Department of Mathematics Education, Universitas Pendidikan Indonesia, Bandung, Indonesia
}

*Corresponding author: rizkiramadhani@upi.edu

\begin{tabular}{|c|c|}
\hline Arti & ABSTRACT \\
\hline Article history: & \multirow{10}{*}{$\begin{array}{l}\text { This study examines the effect of the inquiry learning model on the } \\
\text { mathematical problem solving ability of students in Indonesia } \\
\text { through meta-analysis. This study analyzed seven primary studies } \\
\text { that met the inclusion criteria. The effect size index was calculated } \\
\text { using the Hedges g equation and statistical analysis using } \\
\text { comprehensive meta-analysis (CMA) software. Effect size testing } \\
\text { is done by analyzing four characteristics, namely class of study, } \\
\text { year of study, and sample size. Based on the results of the analysis } \\
\text { using CMA, the inquiry learning model has a moderate effect } \\
(0.652) \text { on the overall mathematical problem-solving skills of } \\
\text { students. The use of the inquiry learning model is more effectively } \\
\text { used in } 7 \text { th-grade, in the range of } 2015-2017 \text { and } 2018-2020 \text {, the } \\
\text { sample size is less than or equal to } 30 \text {. Thus, it can be seen that the } \\
\text { inquiry learning model is useful in improving mathematical } \\
\text { problem-solving skills. }\end{array}$} \\
\hline Received: August 20, 2021 & \\
\hline Accer & \\
\hline 2021 & \\
\hline Published: Nov & \\
\hline & \\
\hline Keywords: & \\
\hline Inqui & \\
\hline & \\
\hline lving skills & \\
\hline
\end{tabular}

\section{META-ANALISIS PENGARUH MODEL PEMBELAJARAN INKUIRI TERHADAP KEMAMPUAN PEMECAHAN MASALAH MATEMATIS SISWA}

\section{Kata Kunci:}

Model pembelajaran inkuiri

Meta-analisis

Pemecahan masalah

\section{ABSTRAK}

Penelitian ini menguji pengaruh model pembelajaran inkuiri terhadap kemampuan pemecahan masalah matematis siswa di Indonesia melalui meta-analisis. Penelitian ini menganalisis tujuh studi primer yang memenuhi kriteria inklusi. Indeks effect size menggunakan persamaan Hedges $g$ dan analisis statistik menggunakan bantuan perangkat lunak comprehensive metaanalysis (CMA). Pengujian effect size dilakukan dengan menganalisis empat karakteristik yaitu kelas studi, tahun studi, dan ukuran sampel. Berdasarkan hasil analisis menggunakan CMA, model pembelajaran inkuiri memiliki efek sedang $(0,652)$ terhadap kemampuan pemecahan masalah matematis siswa secara keseluruhan. Penggunaan model pembelajaran inkuiri lebih efektif digunakan pada kelas VII, pada rentang tahun 2015-2017 dan 2018-2020, ukuran sampel kurang dari atau sama dengan 30. Dengan demikian, terlihat bahwa model pembelajaran inkuiri berguna dalam meningkatkan kemampuan pemecahan masalah matematis. 


\section{INTRODUCTION}

Problem-solving ability is one of the mathematical abilities that must be developed. This problem-solving ability is also one of the skills demanded in education in the $21 \mathrm{st}$ century [1]. Problem-solving is an important skill to have because, through problemsolving, individuals can learn the deepening of mathematical concepts by using the application of mathematics to real problems [2]. Practicing problem solving skills in learning aims to equip students with life skills by learning mathematical terms that involve a series of problem solving processes such as analyzing, interpreting, reasoning, predicting, evaluating, and reflecting [3][4]. Based on this, it can be seen that learning in schools needs to develop learning that trains problem-solving skills. This is also in accordance with the provisions of the NCTM that the teaching design for Kindergarten to 12th grade of Senior High School must enable students to develop new knowledge about mathematics through problem-solving, solving problems in both mathematics and other subjects, applying and reflecting on math problem-solving [5]. Therefore, students who have problem solving skills are accustomed to actively participating in finding solutions to solving problems.

To develop problem solving skills, a learning model is needed, one of which is an inquiry learning model. The 2013 curriculum suggests that one model that can be used in learning is the inquiry learning model [1]. The inquiry learning model is a series of student learning activities that emphasize critical and analytical thinking processes to seek and find answers to a problem for themselves [6]. The design of student learning activities in the inquiry learning model aims to make students actively involved in conducting inquiry activities.

The main characteristic of the inquiry learning model is that activities to seek and find knowledge are emphasized to the maximum, all activities carried out by students in learning are expected to foster an attitude of confidence, therefore students are directed to seek and find their own solutions to a problem. The inquiry learning model is used with the aim of developing students' abilities, such as the ability to think systematically, logically, and critically, or intellectual abilities as part of a mental process [7].

Various previous studies from various countries have proven that the use of the inquiry learning model has an effect on students' problem solving abilities, especially in Indonesia [8]-[15]. However, these studies have not further analyzed the effect size of the influence of the inquiry learning model on students' mathematical problem-solving abilities.

Research on the effect of the inquiry learning model on students' mathematical problem solving abilities in terms of different learning characteristics cannot be done with basic learning. However, research can be done by digging up information from various previous studies. In this case, meta-analysis is seen as an objective literature review method because it uses effect sizes. Meta-analysis is a method for collecting study results consistently and precisely [16]. Meta-analysis is a quantitative technique that uses specific measures (e.g., effect size) to demonstrate the strength of the relationship between variables for the studies included in the analysis [17]-[19].

Several studies on meta-analysis have been carried out, such as research analyzing the effect of learning interventions on mathematical thinking skills [20]. There are also studies that analyze the effectiveness of dynamic geometry software applications in learning mathematics [21]. Other research also analyzes the effectiveness of applying realistic mathematics education to students' mathematical abilities in Indonesia [22]. And research that analyzes the effectiveness of constructivism-based learning models on students' mathematical creative thinking skills in Indonesia [23]. Based on some of these studies, it was found that study characteristics such as class of study, year of study, and 
sample size had an influence on the effect size of the learning model on students' mathematical abilities.

From the several studies above, there has been no specific research on meta-analysis on the effect of the inquiry learning model on students' mathematical problem solving skills. As a result, the description of the effectiveness of the inquiry learning model on students' mathematical problem solving abilities as seen from several study characteristics such as class of study, year of study, and sample size has also not been evaluated. Based on these reasons, a comprehensive meta-analysis is needed to determine the magnitude of the influence of the inquiry learning model on students' problem solving abilities. Researchers use this problem as the basis for investigating the influence of the inquiry learning model on students' mathematical problem solving skills. In this context, this study examines the following research questions:

1. How does the inquiry learning model affect students' mathematical problem solving skills?

2. How is the effect of the inquiry learning model on students' mathematical problem solving based on the class of study?

3. How is the effect of the inquiry learning model on students' mathematical problem solving abilities based on the year of study?

4. How is the effect of the inquiry learning model on students' mathematical problem solving based on the sample size?

\section{METHOD}

This study aims to determine the effectiveness of the inquiry learning model on mathematical problem solving for junior high school students in Indonesia. The research method used in this study is a meta-analysis that combines two or more published primary studies. The steps of this research are (1) determining the inclusion criteria for the primary study that will be included in the meta-analysis, (2) empirical data collection procedures, (3) the process of coding study variables, (4) statistical analysis to investigate the relation between variables and effect size, and (5) data presentation of research results.

\subsection{Inclusion Criteria}

The inclusion criteria used in selecting the primary study were; (a) national journal articles in Sinta and Google Scholar; (b) the focus of the article includes experimental and quasi-experimental research in Indonesia on the effect of the inquiry learning model on the mathematical problem solving ability of junior high school students; (c) the articles used have a publication range between 2012-2020; and (d) journal articles have sufficient statistical information (mean, standard deviation, and sample size) to calculate effect size.

\subsection{Data Collection}

Data collection is carried out through an online database that includes Google Scholar, Garuda, Education Resource Center (ERIC), SINTA and URLs of national journals. The keywords used include students' problem solving skills, inquiry learning models, application of inquiry learning models to mathematical problem solving abilities and other relevant keywords. The identification results found 62 studies on the effect of using the inquiry learning model in learning mathematics. At the screening stage to produce primary studies, 54 studies were excluded because they did not meet the inclusion criteria. Then 1 study was excluded from the analysis due to insufficient statistical data. Thus, there were 7 main studies that were eligible for analysis. 


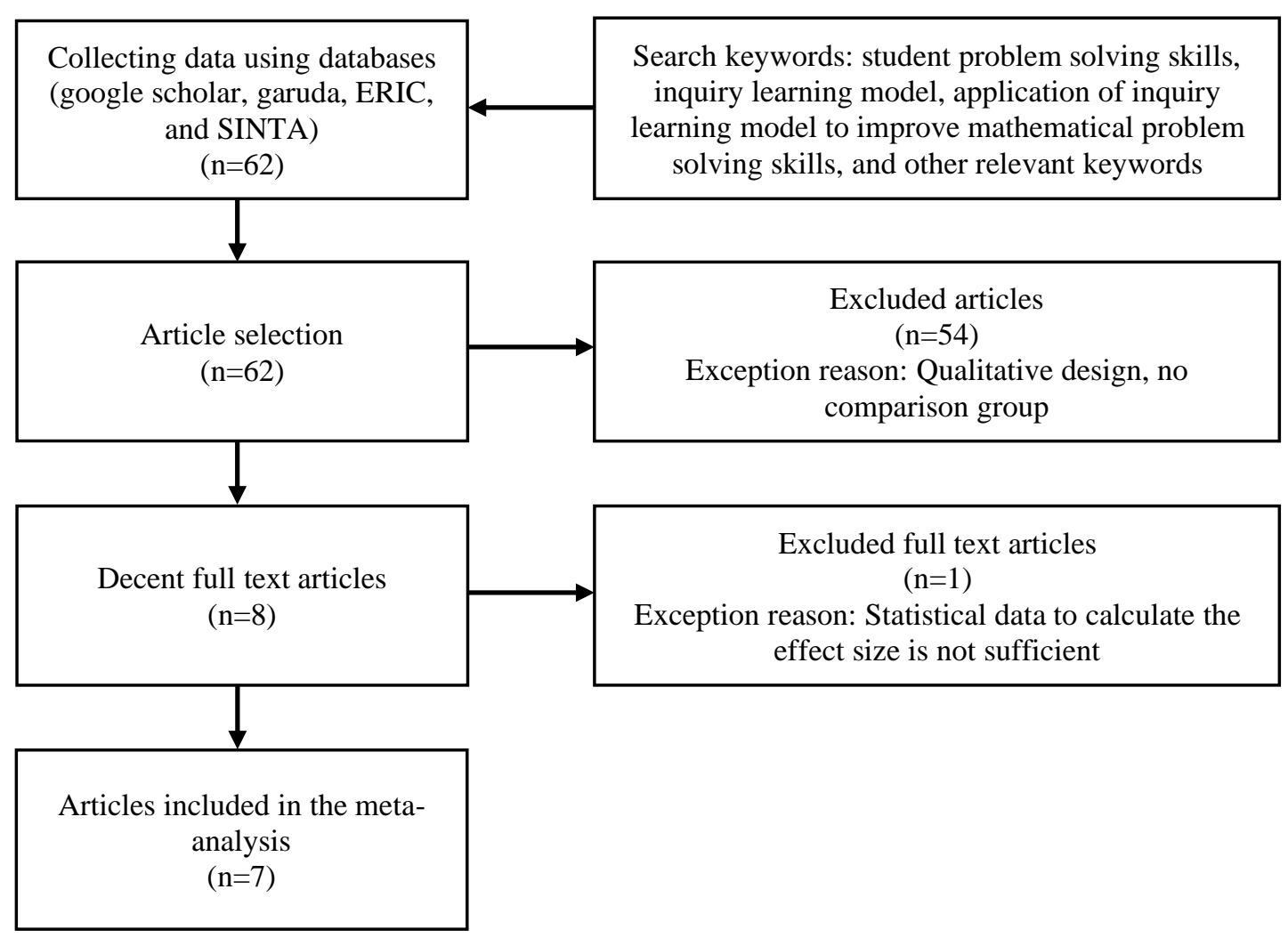

Figure 1. Article Selection Process

\subsection{Coding Process of Study Variables}

The instrument in this study was a coding sheet. The purpose of this coding is to assist researchers in analyzing research data and avoiding data that may be forgotten. The coding in data analysis includes information extracted from the primary study, namely citations, statistical data, experimental class sample size, study class, year of publication, type of publication, name of journal or proceedings, publisher, database, and search links. To minimize subjectivity, two coders were involved. The two coders are students who also conduct research related to meta-analysis. Data coding is done based on the validated coding scheme protocol.

Valid and credible data from the data extraction process were obtained from the coding reliability test, where this reliability test is specifically related to the consistency test between coders. Test coding reliability using Cohen's Kappa $(\kappa(7))$ [24]. Here is Cohen's Cappa formula:

$$
(\kappa(7))=\frac{\operatorname{Pr}(a)-\operatorname{Pr}(e)}{1-\operatorname{Pr}(e)}
$$

With:

$\operatorname{Pr}(a)$ represents a truly observable agreement

$\operatorname{Pr}(e)$ represents a coincidental agreement

Cohen's Kappa reliability test was carried out with the help of SPSS 26. The Kappa coefficient values obtained were interpreted using the Kappa coefficient classification [25]. Kappa coefficient classification is presented in Table 1. 
Table 1. Kappa Coefficient Classification

\begin{tabular}{|c|c|}
\hline Kappa (к) & Interpretation \\
\hline$\kappa<0,00$ & Poor \\
\hline $\mathbf{0 , 0 0} \leq \kappa \leq \mathbf{0 , 2 0}$ & Slight \\
\hline $0,20 \leq \kappa \leq 0,40$ & Fair \\
\hline $0,40 \leq \kappa \leq 0,60$ & Moderate \\
\hline $0,60 \leq \kappa \leq 0,80$ & Substantial \\
\hline $0,80 \leq \kappa \leq 1,00$ & Almost Perfect \\
\hline
\end{tabular}

Based on the Cohen's Kappa reliability test, it was found that the consistency between the two coders for each coding item was in the almost perfect, substantial, and moderate categories.

\subsection{Statistical Analysis}

Effect size is the main foundation in meta-analysis research. Effect size is the magnitude of the effect caused by the parameters tested in the hypothesis [26]. The benefit of using effect size is to see the effect of the relation between variables, and effect size is used to summarize the results of studies in the meta-analysis. Effect size was calculated to assess the consistency of the effect on the overall effect of the study.

Hedge's formula is used in calculating the effect size in this study [27], because the sample size in the primary study used is relatively small [28]. Effect size interpretation uses the effect size category developed by Thalheimer \& Cook [22]. The categories are presented in Table 2.

Table 2. Effect Size Category

\begin{tabular}{cc}
\hline Effect size & Category \\
\hline Effect size $\leq 0,15$ & Neglected \\
$0,15<$ Effect size $\leq 0,40$ & Low \\
$0,40<$ Effect size $\leq 0,75$ & Moderate \\
$0,75<$ Effect size $\leq 1,10$ & High \\
$1,10<$ Effect size $\leq 1,45$ & Very high \\
$1,45<$ Effect size & Excellent \\
\hline
\end{tabular}

In this study, the calculation of the combined effect size and the calculation of the effect size value of the moderator variable used the help of Comprehensive Meta Analysis (CMA) V3.0 software.

Heterogeneity test was conducted to determine the diversity in each effect size. It is also used to determine the estimation model to be applied in the meta-analysis. In this study, heterogeneity test was carried out using Comprehensive Meta Analysis (CMA) V3.0 software. Effect Size between studies is said to be heterogeneous, or can be written statistically as $Q_{b}>\chi_{0,95}^{2}$ and $\mathrm{p}<0,05$, then the homogeneity of the effect size is rejected. This can be interpreted that the effect size between study groups does not measure the same population parameters [27]. In other words, there is a statistically significant difference in the combined effect sizes for each study group.

\section{RESULTS AND DISCUSSION}

In this meta-analysis, seven research articles were used according to the inclusion criteria. The results of calculating the effect size of each research article using the CMA V.3 software are shown in Table 3 . 
Table 3. Effect Size Calculation Results from Each Research

\begin{tabular}{cccccc}
\hline No & Article code & Total Sample & Research Place & Effect Size & Category \\
\hline 1 & A01 & 33 & Ungaran & 0,503 & Moderate \\
2 & A02 & 30 & Tanggamus & 0,479 & Moderate \\
3 & A03 & 34 & Garut & 0,298 & Low \\
4 & A04 & 40 & Bandung & 1,389 & Very High \\
5 & A05 & 26 & Makassar & 1,003 & High \\
6 & A06 & 33 & Bandar Lampung & 0,230 & Low \\
7 & A07 & 29 & Tanjung Bintang & 0,698 & Moderate \\
\hline
\end{tabular}

Based on the results of the calculations in Table 3, it was found that there was one study included in the very high effect size category, one study included in the high effect size category, four studies included in the moderate effect size category, and two studies included in the low effect size category. Furthermore, heterogeneity test was conducted to identify the overall differences in the research articles. The distribution of effect size heterogeneity is shown in Table 4.

Table 4. Heterogeneity distribution effect size

\begin{tabular}{ccccc}
\hline \multicolumn{5}{c}{ Heterogeneity } \\
\hline Q-value & $\mathrm{df}(\mathrm{Q})$ & P-value & I-squared & Q-Table \\
16,225 & 6 & 0,013 & 63,020 & 12,592 \\
\hline
\end{tabular}

Based on Table 4, it is known that the Q-count is 16.225 greater than the Q-table with $\alpha=5 \%$ which is 12.592 . This means that there is a difference in the effect size distribution. Therefore, the random effects model is the model used in conducting further analysis. Furthermore, the publication bias test was carried out using the random effects model to find out whether there were research articles that tended to only publish significant studies which caused the meta-analysis to be too high from the actual effect size [27]. Publication bias tests performed were funnel plot, fail-safe $\mathrm{N}$ from Rosenthal, and trim and fill test. There is no bias if the effect size distribution from the primary study shows a symmetric distribution around the symmetrical funnel plot lines. If the $\mathrm{FSN} /(5 \mathrm{k}+10)>1$ where $\mathrm{k}$ is the number of studies included in the meta-analysis, this study is resistant to publication bias [29]. Trim and Fill was performed to see if any studies were excluded from the analysis. Figure 2 shows the research funnel plot.

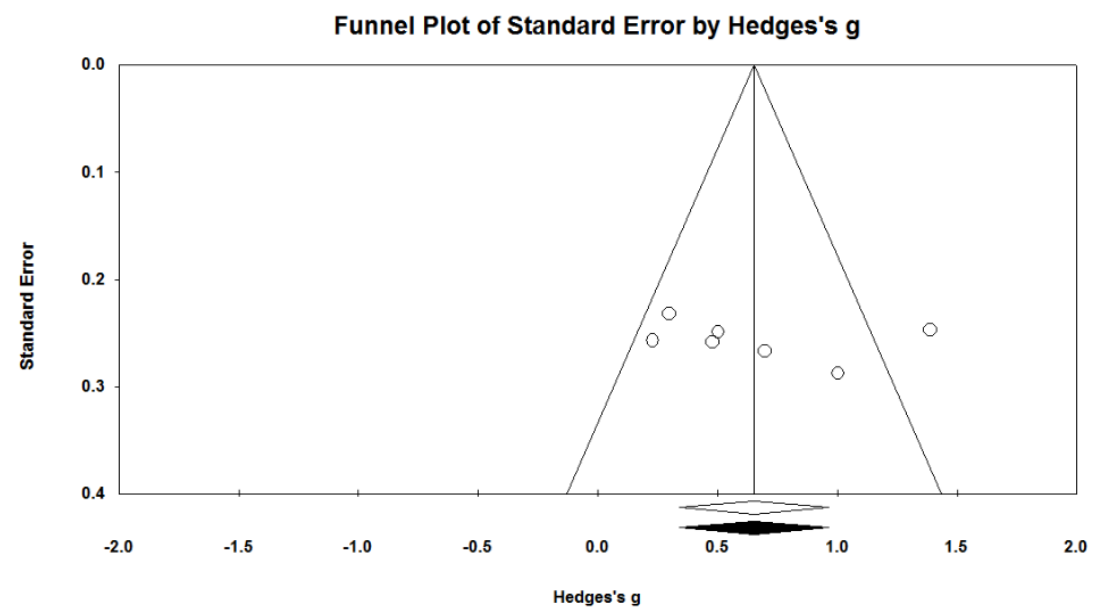

Figure 2. Funnel Plot Effect Size Distribution 
Figure 2 shows that the effect sizes are spread almost symmetrically in the center of the funnel plot and from the left and right sides. The FSN value was used to identify possible publication bias. $\mathrm{N}$ (FSN) in this study was obtained from analysis using CMA V.3 software with a score of 76. Based on the formula of $\frac{N}{(5 k+10)}$ the result is 1,689 . These results indicate that 1.689 is greater than 1 , which means that all studies included in the meta-analysis are not prone to publication bias. Thus, the results of the meta-analysis in this study are stated to be reliable. The results of the Trim and Fill analysis using the CMA V.3 software show that there is no research that needs to be excluded from the analysis. This can be seen in Table 5 .

Table 5. Publication Bias with Trim and Fill Test

\begin{tabular}{lccccc}
\hline & Studies Trimmed & Point Estimate & Lower Limit & Upper Limit & Q-Value \\
\hline Observed values & 0 & 0,65151 & 0,33948 & 0,96353 & 16,22478 \\
Adjusted values & 0 & 0,65151 & 0,33948 & 0,96353 & 16,22478 \\
\hline
\end{tabular}

The results of the analysis of seven studies using the CMA V.3 software are shown in Table 6.

Table 6. Result of Calculation of Effect Size based on Random Effect Model

\begin{tabular}{ccccccccc}
\hline \multirow{2}{*}{ Model } & \multirow{2}{*}{$\mathbf{N}$} & $\mathbf{Z}$ & $\mathbf{p}$ & \multicolumn{4}{c}{ Effect size and 95\% Confidence Interval } \\
\cline { 5 - 8 } & & & Hedge's g & Stardard Error & Variance & Lower Limit & Upper Limit \\
\hline Random & 7 & 4,092 & 0,000 & 0,652 & 0,159 & 0,025 & 0,339 & 0,964 \\
\hline
\end{tabular}

The results of the analysis based on the random effects model from 7 research articles in Table 6 show an effect size of 0.652 with a moderate effect size category, this indicates that the inquiry learning model has a moderate effect on students' mathematical problem solving abilities. Based on the overall analysis based on the random effects model, it was found that the inquiry learning model had a moderate positive effect on students' mathematical problem solving abilities. This finding is supported by research which finds the application of the constructivism learning model to have a more positive effect than the conventional model [23]. In addition, the significance test obtained $\mathrm{p}$ value $<0.05$, which means that the use of the inquiry learning model has a better effect on students' mathematical problem- solving skills compared to conventional learning models. This is also supported by research findings which show that many learning models can improve mathematical abilities, one of which is the inquiry learning model [20]. Furthermore, 95\% confidence interval has a lower limit of 0.339 and an upper limit of 0.964 . The result of Zcount shows the result of 4.092 , this can be said to be statistically significant.

The results of the effect size analysis of the influence of the inquiry learning model on students' mathematical problem solving abilities based on the characteristics of the study using the CMA V.3 software are shown in Table 7.

Table 7. Effect Size Analysis Results based on Study Characteristics

\begin{tabular}{|c|c|c|c|c|c|c|c|c|}
\hline \multirow[b]{2}{*}{$\begin{array}{c}\text { Study } \\
\text { Characteristics }\end{array}$} & \multirow[b]{2}{*}{ Grup } & \multirow[b]{2}{*}{$\mathbf{N}$} & \multirow[b]{2}{*}{ Hedge's g } & \multicolumn{2}{|c|}{ Test of null (2-Tail) } & \multicolumn{3}{|c|}{ Heterogenity } \\
\hline & & & & $\mathbf{Z}$ & p & $\begin{array}{l}\text { Between-Classes } \\
\text { Effect }(\mathbf{Q b})\end{array}$ & $\operatorname{df}(Q)$ & $\mathbf{P}$ \\
\hline \multirow{2}{*}{ Grade } & VII & 2 & 1,059 & 4,486 & 0,000 & \multirow{2}{*}{4,234} & \multirow{2}{*}{1} & \multirow{2}{*}{0,040} \\
\hline & VIII & 5 & 0,485 & 3,251 & 0,001 & & & \\
\hline \multirow{3}{*}{ Academic Year } & $2012-2014$ & 2 & 0,491 & 1,400 & 0,161 & \multirow{3}{*}{0,301} & \multirow{3}{*}{2} & \multirow{3}{*}{0,860} \\
\hline & $2015-2017$ & 4 & 0,723 & 2,910 & 0,004 & & & \\
\hline & $2018-2020$ & 1 & 0,698 & 1,388 & 0,165 & & & \\
\hline \multirow{2}{*}{ Sample Size } & $\leq 30$ & 3 & 0,720 & 2,685 & 0,007 & \multirow{2}{*}{0,109} & \multirow{2}{*}{1} & \multirow{2}{*}{0,741} \\
\hline & $\geq 31$ & 4 & 0,604 & 2,682 & 0,007 & & & \\
\hline
\end{tabular}


Table 7 shows that the effect size of the 7 th grade group gets a value of 1,059 which is included in the high effect size category. While the effect size of the 8th grade group obtained a value of 0.485 which is included in the medium effect size category. Thus, it can be concluded that the influence of the inquiry learning model on mathematical problem solving abilities is greater in grade 7 students than grade 8 students [23][30]. The results of the heterogeneity test showed a Q-count value of 4.234. While the Q-table with $\alpha=5 \%$ and $\mathrm{df}=1 \mathrm{~s} 3.841$. This means that there is a significant difference in effect size between study groups based on study class. In other words, the effect of using the inquiry learning model on mathematical problem solving abilities between study groups is different based on the class of study. This study is consistent with the results of the study which found that there were differences in effects between study groups based on study class [31][30].

The effect size analysis on the influence of the inquiry learning model on students' mathematical problem solving abilities shows that the effect size of the 2012-2014 academic year group is 0.491 which is included in the medium effect size category. The effect size of the 2015-2017 academic year group is 0.723 which is included in the medium effect size category. Meanwhile, the effect size of the 2018-2020 academic year group is 0.698 which is included in the medium effect size category. The results of the heterogeneity test based on the year of study showed a Q-count value of 0.301. While the Q-table with $\alpha=5 \%$ and $\mathrm{df}=2$ is 5,991 . This indicates that there is no significant difference in effect size between study groups based on the year of study. In other words, the effect of using the inquiry learning model on students' mathematical problem solving abilities between study groups did not differ based on the year of study. This finding is in line with the results of previous studies which found that there was no difference in effects between study groups based on the year of study [30][32]-[34].

The effect size analysis of the influence of the inquiry learning model on students' mathematical problem solving abilities shows that the effect size of the sample size group $\leq 30$ is 0.720 which is included in the medium category. While in the group with a sample size of $\geq 31$ is 0.604 which is included in the medium category. The results of the heterogeneity test based on the sample size showed a Q-count value of 0.109 . While the Q-table with $\alpha=5 \%$ and $\mathrm{df}=1$ is 3,841. This means that there is no significant difference in effect size between study groups based on sample size. In other words, the effect of using the inquiry learning model on students' mathematical problem solving abilities between study groups did not differ based on the sample size. This means that the sample size does not change the effect size. This study is consistent with previous research which found that the study sample size did not change the effect size of the study [30][33][35]-[36]. However, this is different from the results of other studies which found differences in the effectiveness of treatment in learning based on sample size [21]-[22][37]. The difference in the results of this study can be further investigated by further researchers.

Based on the results of the research, the inquiry learning model as a whole has a positive effect on students' mathematical problem solving abilities, it is expected that teachers can use the inquiry learning model in learning mathematics. The results of the study based on the characteristics of the study showed that the inquiry learning model on students' mathematical problem solving abilities was more effective in grade 7 with a total of 30 students in one class. This can be used as a guide for teachers in developing creative learning models. These findings can also be used as consideration for other researchers who want to conduct research on the use of inquiry learning model. 


\section{CONCLUSION}

This research was conducted to determine the effectiveness of the inquiry learning model on mathematical problem solving skills through meta-analysis. Based on the random effects model, the effect size value is 0.652 in the moderate category. In other words, the overall effect of the inquiry learning model on students' mathematical problem solving abilities is in the moderate effect size category.

Based on the characteristics of the study class, there are differences in effect size between class groups. Meanwhile, judging from the characteristics of the academic year and sample size, there is no difference in effect size between groups. The results showed that the effect of the inquiry learning model in grade 7 was greater than grade 8 , the effect of the inquiry learning model conducted in 2015-2017 and 2018-2020 was higher than in 2012-2014, and the effect of the inquiry learning model carried out with a total sample of $\leq 30$ is larger than the research with total sample $\geq 31$. This fact can be taken into consideration for teachers in implementing the inquiry learning model in the future.

\section{REFERENCES}

[1] Kemendikbud, Modul Manajemen Implementasi Kurikulum 2013. Jakarta: Kemendikbud, 2018.

[2] D. Beigie, "Integrating Content to Create Problem-Solving Opportunities," Math. Teach. Middle Sch., vol. 13, no. 6, 2008.

[3] J. Anderson, "Mathematics Curriculum Development and the Role of Problem Solving," 2009.

[4] J. Kilpatrick, J. Swafford, and B. Findell, Adding It Up: Helping Children Learn Mathematics. United States of America: National Academy Press, 2001.

[5] NCTM, Principles and Standards for School Mathematics. United States of America: Library of Congress, 2000.

[6] Asnidar, S. Khabibah, and R. Sulaiman, "The Effectiveness of Guided Inquiry Learning for Comparison Topics," J. Phys. Conf. Ser., vol. 947, no. 1, 2017, doi: 10.1088/1742-6596/947/1/012033.

[7] W. Sanjaya, Strategi Pembelajaran. Jakarta: Kencana Prenada Media Group, 2014.

[8] D. Kurniawati, S. Sutiarso, and Widyastuti, "Efektivitas Model Pembelajaran Inkuiri Berbasis Ethnomathematics Terhadap Kemampuan Pemecahan Masalah Matematis Siswa," J. Pendidik. Mat. Unila, vol. 6, pp. 293-304, 2018.

[9] N. Solikhah, E. R. Winarti, and A. W. Kurniasih, "Keefektifan Model Guided Inquiry dengan Pendekatan Keterampilan Metakognitif terhadap Kemampuan Pemecahan Masalah," J. Kreano, vol. 5, no. 1, pp. 18-25, 2014, doi: 10.15294/kreano.v5i1.3273.

[10] Y. Meidawati, "Pengaruh Pendekatan Pembelajaran Inkuiri Tebimbing Terhadap Peningkatan Kemampuan Pemecahan Masalah Matematis Siswa SMP," $J$. Pendidik. dan Kegur., vol. 1, no. 2, 2014.

[11] G. Nadhifah and E. A. Afriansyah, "Peningkatan Kemampuan Pemecahan Masalah Matematis Siswa dengan Menerapkan Model Pembelajaran Problem Based Learning dan Inquiry," J. Musharafa, vol. 5, no. 1, pp. 33-44, 2016.

[12] V. N. Yulian, "Meningkatkan Kemampuan Pemecahan Masalah Matematis Siswa Melalui Metode Pembelajaran Metode Inkuiri Berbantuan Software Algebrator," Jppm, vol. 9, no. 1, pp. 20-24, 2016.

[13] M. Zulfikar, T. Tayeb, and Mardhiah, "Perbandingan Penerapan Metode Inquiry Terbimbing Dan Metode Inquiry Bebas Termodifikasi Terhadap Kemampuan Pemecahan Masalah Matematika Siswa," Alauddin J. Math. Educ., vol. 1, no. 1, 
2017.

[14] M. D. Bidari, R. Asnawati, and Widyastuti, "Efektivitas Model Pembelajaran Guided Inquiry Ditinjau dari Kemampuan Pemecahan Masalah Matematis Siswa," J. Pendidik. Mat. Unila, vol. 5, no. 8, pp. 914-925, 2017.

[15] A. Pinasti, R. Asnawati, and A. P. Wijaya, "Efektivitas Model Pembelajaran Inkuiri Terbimbing untuk Meningkatkan Kemampuan Pemecahan Masalah Matematis Siswa," J. Pendidik. Mat. Unila, vol. 7, no. 3, pp. 310-321, 2019.

[16] L. V. Hedges and I. Olkin, Statistical Methods for Meta-Analysis. Florida: Academic Press, 1985.

[17] T. J. Cleophas and A. H. Zwinderman, Modern Meta-Analysis. Switzerland: Springer, 2017.

[18] G. Schwarzer, J. R. Carpenter, and G. Rücker, Meta-Analysis with R. Switzerland: Springer, 2015.

[19] L. B. Shelby and J. Vaske, "Understanding meta-analysis: A review of the methodological literature," Leis. Sci., vol. 30, no. 2, pp. 96-110, 2008, doi: $10.1080 / 01490400701881366$.

[20] K. Kadir, "Meta-Analysis of the Effect of Learning Intervention Toward Mathematical Thinking on Research and Publication of Student," TARBIYA J. Educ. Muslim Soc., vol. 4, no. 2, pp. 162-175, 2017, doi: 10.15408/tjems.v4i2.8010.

[21] D. Juandi et al., "The Effectiveness of Dynamic Geometry Software Applications in Learning Mathematics: A Meta-Analysis Study," Int. J. Interact. Mob. Technol., vol. 15, no. 2, pp. 18-37, 2021, doi: 10.3991/ijim.v15i02.18853.

[22] M. Tamur, D. Juandi, and A. M. G. Adem, "Realistic Mathematics Education in Indonesia and Recommendations for Future Implementation: A Meta-Analysis Study," JTAM | J. Teor. dan Apl. Mat., vol. 4, no. 1, p. 17, 2020, doi: 10.31764/jtam.v4i1.1786.

[23] M. Tamur and D. Juandi, "Effectiveness of constructivism based learning models against students mathematical creative thinking abilities in indonesia; a metaanalysis study," 2020, doi: 10.4108/eai.12-10-2019.2296507.

[24] M. L. McHugh, "Lessons in biostatistics interrater reliability: the kappa statistic," Biochemica Medica, vol. 22, no. 3. pp. 276-282, 2012, [Online]. Available: https://hrcak.srce.hr/89395.

[25] A. J. Viera and J. M. Garrett, "Understanding Interobserver Agreement: The Kappa Statistic," Fam. Med., vol. 37, no. 5, 2005.

[26] D. Juandi and M. Tamur, Pengantar Analisis Meta. Bandung: UPI Press, 2020.

[27] M. Borestein, L. V. Hedges, J. P. T. Higgins, and H. R. Rothstein, Introduction to meta-analysis. United Kingdom: John Wiley \& Sons, 2009.

[28] M. W. Lipsey and D. B. Wilson, Practical Meta Analysis. United Stated of America: SAGE Publications, 2001.

[29] B. Mullen, P. Muellerleile, and B. Bryant, "Cumulative meta-analysis: A consideration of indicators of sufficiency and stability," Personal. Soc. Psychol. Bull., vol. 27, no. 11, pp. 1450-1462, 2001, doi: 10.1177/01461672012711006.

[30] N. Susanti, D. Juandi, and M. Tamur, "The Effect of Problem-Based Learning (PBL) Model On Mathematical Communication Skills of Junior High School Students - A Meta-Analysis Study," JTAM (Jurnal Teor. dan Apl. Mat., vol. 4, no. 2, p. 145, 2020, doi: 10.31764/jtam.v4i2.2481.

[31] F. Dochy, M. Segers, P. Van den Bossche, and D. Gijbels, "Effects of problembased learning: A meta-analysis from the angle of assessment," Learn. Instr., vol. 75, no. 1, 2002, doi: 10.3102/00346543075001027. 
[32] Ö. G. Bayir and M. Bozkurt, "Effectiveness of Cooperative Learning Approaches Used in the Course of Social Studies in Turkey: a Meta-Analysis Study," Eur. J. Educ. Stud., vol. 4, no. 10, pp. 171-192, 2018.

[33] M. F. B. Paloloang, D. Juandi, M. Tamur, B. Paloloang, and A. M. G. Adem, "Meta Analisis: Pengaruh Problem-Based Learning Terhadap Kemampuan Literasi Matematis Siswa Di Indonesia Tujuh Tahun Terakhir," AKSIOMA J. Progr. Stud. Pendidik. Mat., vol. 9, no. 4, pp. 851-864, 2020.

[34] M. Tamur, E. Jehadus, F. Nendi, K. Mandur, and V. Murni, "Assessing the effectiveness of the contextual teaching and learning model on students' mathematical understanding ability: A meta-analysis study," J. Phys. Conf. Ser., vol. 1657, no. 1, 2020, doi: 10.1088/1742-6596/1657/1/012067.

[35] Suparman, D. Juandi, and M. Tamur, "Review of problem-based learning trends in 2010-2020: A meta-analysis study of the effect of problem-based learning in enhancing mathematical problem-solving skills of Indonesian students," J. Phys. Conf. Ser., vol. 1722, no. 1, pp. 0-9, 2021, doi: 10.1088/1742-6596/1722/1/012103.

[36] Y. Yunita, D. Juandi, M. Tamur, A. M. G. Adem, and J. Pereira, "A meta-analysis of the effects of problem-based learning on students' creative thinking in mathematics," Beta J. Tadris Mat., vol. 13, no. 2, pp. 104-116, 2020, doi: 10.20414/betajtm.v13i2.380.

[37] Y. K. Sari, D. Juandi, M. Tamur, and A. M. G. Adem, "Meta-Analysis: Mengevaluasi Efektivitas Problem-Based Learning Pada Kemampuan Pemahaman Matematis Siswa," J. Honai Math, vol. 4, no. 1, pp. 1-18, 2021. 